\title{
Faktor-Faktor Pendukung \& Penghambat Implementasi Program Corporate Social Responsibility dalam Membantu Kehidupan Masyarakat Sekitar Perkebunan
}

\section{Supporting \& Barrier Factors of Corporate Social Responsibility Implementation In Helping People's Lives Around Plantation}

\author{
Rizka Rahmah Hidayati*, Badaruddin \& R. Hamdani Harahap \\ Program Magister Studi Pembangunan, Universitas Sumatera Utara, Indonesia
}

Diterima: 26 Agustus 2020; Disetujui: 20 Desember 2020; Diterbitkan: 31 Januari 2021.

\begin{abstract}
Abstrak
Penelitian ini bertujuan untuk menganalisis faktor - faktor pendukung \& penghambat implementasi program corporate social responsibility PT. PP London Sumatra Indonesia, Tbk dalam membantu kehidupan masyarakat Perkebunan Bagerpang, Kabupaten Deli Serdang - Provinsi Sumatera Utara. Metode penelitian dilakukan dengan pendekatan kualitatif dengan menggunakan teknik pengumpulan data melalui wawancara dan observasi lapangan. Informan dalam penelitian ini terdiri dari masyarakat penerima program CSR, pihak manajemen perusahaan yang menangani bagian CSR dan aparatur pemerintah desa setempat. Lokasi penelitian mencakup wilayah Bagerpang Estate yang terdiri dari 7 divisi/desa di 3 kecamatan yaitu Kecamatan Galang, Bangun Purba dan STM Hilir. Hasil penelitian menunjukkan bahwa PT. PP London Sumatra Indonesia,Tbk sebagai perusahaan swasta di bidang agro industri turut berpartisipasi membantu pemerintah dalam pembangunan melalui implementasi program CSR sebagai bentuk tanggung jawab sosial terhadap masyarakat dan lingkungan atas dampak yang ditimbulkan dari kegiatan operasionalnya. PT. PP London Sumatra Indonesia,Tbk telah melaksanakan praktik CSR pada beberapa bidang kerja yakni pendidikan, kesehatan, pemeliharaan infrastruktur, sosial dan keagamaan dan usaha ekonomi kerakyatan. Peneliti juga menemukenali beberapa faktor pendukung dan penghambat keberhasilan dan efektivitas implementasi CSR tersebut. Kesimpulan dari penelitian ini adalah perusahaan masih memfokuskan tujuan dan sasaran implementasi CSR nya pada level peningkatan kualitas hidup karyawan dan keluarganya belum pada level pemberdayaan masyarakat.

Kata Kunci: Implementasi, Corporate Social Responsibilit, Faktor Pendukung, Faktor Penghambat
\end{abstract}

\begin{abstract}
This research aims to analyze the supporting \& barrier factors of the implementation of corporate social responsibility program of PT. PP London Sumatra Indonesia, Tbk in helping the lives of the people around Bagerpang Plantation, Deli Serdang Regency - North Sumatra Province. Research methods are carried out with a qualitative approach using data collection techniques through interviews and field observations. The informants in this study consisted of CSR program recipients, corporate management who handle CSR departments and local village government apparatus. The research site covers Bagerpang estate which consists of 7 divisions / villages in 3 sub-districts namely Galang, Bangun Purba and STM Hilir. The results showed that PT. PP London Sumatra Indonesia, Tbk as a private company in the field of agro industry participated in assisting the government in development through the implementation of CSR programs as a form of social responsibility to the community and the environment for the impact sparked by its operational activities. PT. PT. PP London Sumatra Indonesia, Tbk has implemented CSR practices in several areas of work, namely education, health, infrastructure maintenance, social and religious and populist economic efforts. Researcher also introduced several supporting and barrier factors of the success and effectiveness of CSR implementation. The conclusion of this research is that the company is still focusing its CSR implementation goals and objectives on improving the quality of life of employees and their families not yet on the level of community empowerment.

Keywords: Implementation, Corporate Social Responsibility, Supporting Factors, Barrier Factors.
\end{abstract}

How to Cite: Hidayati, R.R. Badaruddin \& Harahap, H. (2021). Faktor -Faktor Pendukung \& Penghambat Implementasi Program Corporate Social Responsibility Dalam Membantu Kehidupan Masyarakat Sekitar Perkebunan. PERSPEKTIF, 10 (1): 66-79

*Corresponding author: ISSN 2085-0328 (Print)

E-mail: rizkarahmah@gmail.com ISSN 2541-5913 (online) 
Rizka Rahmah Hidayati, Badaruddin \& R. Hamdani Harahap, Faktor-Faktor Pendukung \&

\section{PENDAHULUAN}

Trickle down effect adalah dampak positif yang diharapkan pemerintah dari pertumbuhan ekonomi yang tinggi yang diperoleh melalui kegiatan pembangunan. Dari dampak positif pembangunan tersebut, seperti tumbuhnya sektor industri di segala bidang, diharapkan terdapat peningkatan pendapatan dan terbukanya kesempatan kerja bagi segala lapisan masyarakat. Dengan kata lain manfaat dari kegiatan ekonomi yang besar akan berimbas kepada kegiatan ekonomi yang lebih kecil. Kenyataannya, pertumbuhan ekonomi hanya dinikmati oleh para pemilik modal dan para elit terkait, tidak terciptanya pemerataan hasil - hasil pembangunan. Kegiatan ekonomi dalam skala besar nyatanya tidak memberikan keuntungan bagi kegiatan perekonomian yang lebih kecil. Korporasi dibangun untuk menguasai lahan bisnis dan kepemilikan aset aset ekonomi. Hal ini makin mempersempit kesempatan masyarakat untuk berusaha dan makin memperlebar jurang pemisah antara kehidupan para pemilik modal dan masyarakat kebanyakan (Sari, 2020).

Menurut Soleh (2012), pertumbuhan ekonomi sebagai akibat dari kegiatan produksi yang dilakukan para pemilik modal akan otomatis menetes ke bawah dalam bentuk penyediaan lapangan pekerjaan dan berbagai peluang usaha sehingga pertumbuhan ekonomi tersebut juga dirasakan manfaatnya oleh masyarakat. Kegiatan ekonomi dari tahapan produksi, distribusi sampai pada rantai konsumsi merupakan suatu aliran yang berkesinambungan dan pasti melibatkan pemilik modal/para elit dan masyarakat. Terjadinya pertumbuhan ekonomi akan berpengaruh kepada penurunan angka kemiskinan dengan kondisi kemiskinan akan berkurang dalam skala yang sangat kecil bila penduduk miskin hanya menerima sedikit manfaat dari total manfaat yang ditimbulkan dari adanya pertumbuhan ekonomi dimana peningkatan pendapatan berada di pihak pemilik modal/para elit. Hasil penelitian yang dilakukan Soleh menunjukkan bahwa tingginya pertumbuhan ekonomi suatu tempat tidak menjamin kesejahteraan penduduk di tempat tersebut, sebagai contoh Provinsi Papua Barat memiliki rata - rata pertumbuhan ekonomi tertinggi secara nasional dengan persentase $11,27 \%$ per tahun, yang memiliki pendapatan asli daerah terbesar berasal dari eksplorasi SDA
Migas, namun berkah sumber daya alam tersebut berlawanan dengan keberadaan penduduk miskin yang memiliki persentase 35,77\%. Fenomena ini menunjukkan pertumbuhan ekonomi tidak selaras dengan kesejahteraan penduduk suatu daerah.

Menurut Undang - Undang No. 11 Tahun 2009, kesejahteraan sosial adalah kondisi terpenuhinya kebutuhan material, spiritual, dan sosial warga negara agar dapat hidup layak dan mampu mengembangkan diri, sehingga dapat melaksanakan fungsi sosialnya. Masih terdapatnya warga negara yang belum bisa memenuhi kebutuhan dasarnya secara layak menunjukkan bahwa permasalahan tentang kesejahteraan ini belum tuntas sampai saat ini.

Wrihatnolo dan Nugroho dalam bukunya yang berjudul Manajemen Pembangunan Indonesia (2008) melihat bahwa kesejahteraan masyarakat dapat diciptakan melalui program pembangunan. Di Indonesia, program program pembangunan tidak selalu sesuai dengan perencanaan yang dibuat. Terdapat beberapa kendala/hambatan yang harus dihadapi dalam mewujudkan rencana pembangunan tersebut, salah satunya adalah masalah pembiayaan pembangunan. Hal ini dikarenakan pelaksanaan program - program pembangunan membutuhkan biaya yang sangat besar dan tidak seluruhnya mampu dibiayai oleh APBN. Oleh karena itu, perlu dicarikan alternatif sumber dana agar program - program pembangunan tersebut dapat dijalankan.

Tujuan dan sasaran pembangunan, motivasi aktor pembangunan, dan ketersediaan biaya merupakan faktor penting untuk menciptakan kesejahteraan manusia. Kesejahteraan manusia merupakan fokus utama pembangunan. Kesejahteraan manusia dalam konteks bernegara berarti kesejahteraan masyarakat. Selanjutnya, sejalan dengan pelaksanaan tujuan pembangunan berkelanjutan yang memasuki tahun ke lima, masih banyak tantangan yang harus dihadapi oleh Negara Indonesia dalam mencapai indikator keberhasilan pembangunan berkelanjutan tersebut. Pencapaian MDGs di Indonesia perlu melibatkan partisipasi banyak pihak, yaitu pemerintah, lembaga legislatif, pelaku usaha, ormas, media massa, serta akademisi dan praktisi dalam hal pelaksanaan, inovasi, dan pembiayaan. Bagi perusahaan, peran serta yang bisa diambil dalam 
pencapaian tujuan pembangunan berkelanjutan ini salah satunya ialah komitmen dalam pelaksanaan CSR. Menurut Maszoom (2016), CSR dapat dimanfaatkan untuk percepatan sasaran prioritas pembangunan dan peningkatan kesejahteraan masyarakat. Pelaksanaan program CSR perlu diselaraskan dengan program pembangunan yang dilaksanakan oleh pemerintah agar jenis dan output kegiatan CSR tidak tumpang tindih dengan program pemerintah.

Aturan tentang Tanggung Jawab Sosial Perusahaan tercantum dalam Undang - Undang Nomor 40 Tahun 2007 tentang Perseroan Terbatas dan pada Pasal 1 Angka 3 tertulis "Tanggung Jawab Sosial dan Lingkungan adalah komitmen perseroan untuk berperan serta dalam pembangunan ekonomi berkelanjutan guna meningkatkan kualitas kehidupan dan lingkungan yang bermanfaat, baik bagi perseroan sendiri, komunitas setempat, maupun masyarakat pada umumnya".

Aturan lain tentang kewajiban bina lingkungan juga terdapat pada Undang Undang No. 25 Tahun 2007 tentang Penanaman Modal dimana pada pasal 15 tertuang "Setiap penanggung jawab usaha dan/atau kegiatan wajib melakukan pengelolaan limbah hasil usaha dan/atau kegiatan", dan pada pasal 16 tertuang "Setiap penanggung jawab usaha dan/atau kegiatan wajib melakukan pengelolaan bahan berbahaya dan beracun". Selanjutnya, Keputusan Menteri BUMN Nomor: Kep-236/MBU/2003 mengatur tentang Program Kemitraan Badan Usaha Milik Negara dengan Usaha Kecil dan Program Bina Lingkungan (PKBL). Aturan - aturan yang dibuat pemerintah tentang kewajiban pelaksanaan CSR bagi perusahaan ini merupakan salah satu upaya pemerintah agar masyarakat juga merasakan manfaat dari pertumbuhan ekonomi di Indonesia dan menjaga kelestarian lingkungan.

Berdasarkan hal di atas dan melihat banyaknya manfaat dari pengaplikasian program CSR, dapat memberikan gambaran pada kita bahwa implementasi program CSR bisa menjadi salah satu upaya dalam pembangunan dalam hal pendidikan, kesehatan, sosial, ekonomi, dan lingkungan sehingga studi tentang program CSR yang dilakukan perusahaan masih sangat relevan dan menarik untuk diteliti.

\section{METODE PENELITIAN}

Peneliti menggunakan pendekatan kualitatif dalam penelitian ini dan teknik pengumpulan data melalui wawancara dan observasi lapangan. Jenis data dalam penelitian ini terdiri dari data utama/primer dan data kedua/sekunder. Data utama/primer dalam penelitian ini adalah hasil wawancara dan observasi lapangan ke wilayah Perkebunan Bagerpang. Sedangkan data kedua/sekunder berupa hasil laporan dan dokumentasi program corporate social responsibility yang telah dirangkum oleh pihak PT. PP London Sumatra Indonesia, Tbk. Melalui tahapan wawancara dan observasi ini, peneliti mencoba membandingkan antara hasil laporan pihak perusahaan tentang implementasi CSR dengan kenyataan di lapangan.

Peneliti mengumpulkan data dari informan yang terdiri dari orang - orang yang mengetahui / terlibat langsung dalam pelaksanaan program CSR ini diantaranya : masyarakat sekitar Perkebunan Bagerpang selaku penerima program CSR, manajemen perusahaan PT. PP London Sumatra Indonesia, Tbk yang menangani bagian CSR, dan aparat pemerintah desa/dusun setempat. Lokasi penelitian mencakup wilayah Bagerpang Estate yang terdiri dari 7 divisi/desa di 3 kecamatan yaitu Kecamatan Galang, Bangun Purba dan STM Hilir.

Data yang diperoleh dari hasil penelitian dianalisis melalui beberapa tahapan yakni reduksi data, penyajian data, kesimpulan dan verifikasi. Pada tahapan reduksi data yang peneliti lakukan adalah dengan mengumpulkan seluruh catatan lapangan berdasarkan wawancara dan observasi yang telah dilakukan kemudian melengkapinya dengan data sekunder. Data hasil wawancara dan observasi tersebut disimpan dalam bentuk rekaman, dokumentasi dan catatan - catatan penelitian. Pada tahapan reduksi data, peneliti memilih data mana saja yang relevan dan berkaitan dengan rumusan masalah yang diajukan karena data kualitatif sangat banyak, kemudian peneliti buat dalam sebuah narasi agar mudah dalam menyajikannya. Analisis data menurut Nasution (1991:126) adalah "proses menyusun data agar dapat ditafsirkan, menyusun data berarti menggolongkannya dalam pola, tema atau kategori."

Selanjutnya setelah melakukan interpretasi hasil wawancara dan observasi 
lapangan, pada tahapan penyajian data peneliti membuat dalam bentuk naratif. Penyajian data semacam ini peneliti pilih karena lebih mudah difahami dan dilakukan. Tabel dan gambar disajikan sebagai pelengkap saja. Langkah terakhir dalam analisis data kualitatif adalah penarikan kesimpulan dan verifikasi. Logika yang dipergunakan dalam penarikan kesimpulan dalam penelitian kualitatif bersifat induktif (dari yang khusus kepada yang umum).

\section{HASIL DAN PEMBAHASAN Cikal Bakal Implementasi CSR}

Pada awalnya perusahaan perkebunan, PT PP London Sumatra Indonesia Tbk, merupakan perkebunan Swiss dengan komoditas utama adalah karet. Perusahaan ini bernama The United Serdang (Sumatra) Rubber Plantations Ltd yang didirikan pada tahun 1887 berdasarkan Ketetapan Resident Sumatra Timur tanggal 7 Januari 1887 nomor 40/L. Perusahaan ini kemudian diakuisisi oleh Harisson \& Crossfield (H\&C) yang bermula dari kedatangan Arthur Lampard dari perusahaan Harrisons \& Crossfield ke Sumatera Utara. Kiprah Harrisons \& Crossfield di bidang perkebunan semakin besar dengan basis kegiatan di kota London dan wilayah operasional sebagian besar berada pada wilayah Sumatera.

Pada awal berdirinya Harrisons \& Crossfield Plantation Ltd masih kesulitan memperoleh tenaga kerja untuk menjalankan operasional perusahaan sehingga perusahaan merekrut tenaga kontrak dari luar daerah seperti Jawa dan sekitarnya. Untuk membuat tenaga tersebut betah tinggal di area perkebunan dan juga masyarakat sekitar dapat lebih berinteraksi dengan perusahaan untuk mengamankan suplai tenaga kerja, maka perusahaan melakukan kegiatan sosial berupa pembangunan infrastuktur seperti jalan, jembatan, pasar, tempat hiburan, bangunan fisik dan fasilitas umum lainnya. Selain itu dikarenakan kegemaran dari para pejabat kebun terkait taman dan piaraan, maka hampir disetiap unit kebun dibuat area untuk taman dan konservasi hutan yang sekarang lebih dikenal dengan nama High Conservation Value (HCV).

Selain melakukan pembangunan diberbagai aspek untuk operasional dan daya tarik lokal, perusahaan juga membagi - bagikan tanah untuk pekerja dan keluarganya maupun masyarakat sekitar. Sehingga lama kelamaan menjadi perkampungan dan desa yang berada di dalam maupun sekitar areal perkebunan. Hal ini bertujuan untuk pemenuhan kebutuhan tenaga kerja dengan cara membuat tenaga kerja yang ada beserta kolega kerasan tinggal di kebun dan masyarakat sekitar mau tinggal di sekitar kebun sehingga dapat menjadi mitra maupun tenaga kerja di perusahaan. Inilah cikal bakal tanggung jawab sosial perusahaan yang sekarang lebih dikenal dengan istilah Corporate Social Responsibility (CSR).

Menurut Mugiyanto, STP selaku Sustainability Manager PT. Lonsum untuk wilayah Sumatera Utara, menyatakan bahwa sesuai dengan jargon perusahaan yaitu "TUMBUH DAN BERKEMBANG BERSAMA LONSUM" yang artinya masyarakat tidak hanya menjadi penonton, dengan adanya perusahaan diharapkan masyarakat sekitar juga dapat tumbuh dan berkembang bersama, saling bersinergi dalam hubungan yang saling menguntungkan.

Dalam visi PT. Lonsum tertuang pernyataan "menjadi perusahaan agribisnis terkemuka yang berkelanjutan dalam hal tanaman, biaya, dan lingkungan ( $3 \mathrm{C}: \mathrm{crop}$, cost, condition) yang berbasis penelitian dan pengembangan". Pernyataan ini bermakna bahwa 3C (crop, cost, condition), dimana istilah "condition" meliputi lingkungan fisik dan lingkungan sosial. Berkelanjutan dalam hal lingkungan sosial adalah bentuk tanggung jawab sosial perusahaan sehingga menciptakan kondisi sosial yang kondusif dan mampu menopang keberlanjutan perusahaan.

Terkait dana penyelenggaraan program CSR PT. Lonsum, menurut Kiki Ningrum, Community Development Officer PT. Lonsum,

"Anggaran dana berasal dari annual operational plan (AOP) yang dianggarkan setiap tahunnya, besaran AOP untuk dana CSR tidak sama pertahunnya, disusun berdasarkan kebutuhan masing-masing unit lokasi, urgensi pelaksanaannya, evaluasi kegiatan sebelumnya dan juga kondisi cash flow perusahaan".

Mekanisme penganggaran dana CSR PT. Lonsum dapat dijelaskan sebagai berikut: 1) Inventariasi dan pembuatan anggaran (AOP) oleh unit dan area manager sustainability; 2) Review \& Approval oleh Head of Sustainability Department; 3) Review dan Approval BoD Group (IndoAgri); 4) Implementasi program CSR oleh 
sustainability department di unit - unit operasional.

Pandangan Maygarindra (2012) tentang analisis alokasi dana CSR, mengemukakan bahwa suatu perusahaan menunjukkan konsistensinya dalam menjalankan program CSR tercermin dari peningkatan anggaran yang dialokasikan untuk kegiatan ini setiap tahunnya.

\section{Manfaat Program CSR}

Berdasarkan hasil penelitian dan olah data sekunder monitoring program kerja CSR Bagerpang Estate tahun 2018 dan 2019, PT. PP London Sumatra Indonesia, Tbk telah melaksanakan beberapa bidang kerja CSR yakni pendidikan melalui program beasiswa berprestasi, kesehatan melalui program posyandu dan operasi bibir sumbing, pemeliharaan infrastruktur melalui program peminjaman alat - alat berat untuk pemeliharaan jalan dan drainase, sosial dan keagamaan melalui program rumah pintar dan kegiatan keagamaan selama bulan Ramadhan, dan usaha ekonomi kerakyatan melalui pelatihan - pelatihan keterampilan di sentra kriya.

Menurut Kepala Desa Ujung Rambe, Bapak Dian Ika,

"Dari beberapa perusahaan yang berada di wilayah pemerintahan desa yang saya pimpin, PT. Lonsum merupakan perusahaan yang cepat tanggap dalam hal permintaan bantuan alat berat untuk memperbaiki sarana jalan dan parit di desa saya. Seperti diketahui sebagian jalan di desa perkebunan masih termasuk kategori jalanan tanah berbatu apabila musim hujan akan sangat berlumpur, licin, dan tentu membahayakan pengendara kendaraan bermotor. Ini sangat membantu kami dikarenakan apabila menyewa alat berat sendiri, sewa alat berat tarifnya tergolong mahal sekitar Rp250.000,00 per jam ditambah lagi kebutuhan BBM nya yang besar dan biaya jasa operatornya. Dengan adanya bantuan dari PT. Lonsum, kami hanya mengeluarkan uang makan dan uang rokok operatornya. Bantuan ini tidak hanya satu - dua kali, sudah berulang kali kami memperoleh bantuan peminjaman alat berat."

Selanjutnya peneliti menanyakan terkait pandangan atau harapan beliau selaku aparat pemerintahan desa tentang program CSR PT. PP London Sumatra Indonesia, Tbk terkait keterlibatan dalam perencanaan, pelaksanaan dan evaluasi kegiatan CSR PT. Lonsum selama ini. Beliau menyatakan bahwa belum pernah diikutsertakan dalam rapat terkait perencanaan hingga evaluasi CSR, namun beliau mengapresiasi dan mendukung penuh program - program CSR yang telah diberikan PT. Lonsum kepada masyarakat desanya. Harapan beliau ke depan PT. Lonsum agar mengagendakan program - program CSR untuk para remaja di desa seperti pengadaan alat alat musik dan sarana olahraga. Selain untuk sarana penyaluran bakat dan hobi para remaja, juga sebagai upaya mengurangi kenakalan remaja melalui kegiatan positif.

Agus Irawan, salah seorang peserta pelatihan pemanfaatan lidi sawit yang telah menjadi pengrajin, menceritakan tentang manfaat yang diperolehnya dari pelatihan tersebut,

"Saya mengikuti pelatihan kerajinan lidi sawit pada tahun 2014 di Rambung Sialang Training Center selama 6 hari dengan peserta berasal dari karyawan perkebunan PT. Lonsum dan masyarakat desa sejumlah 30 orang peserta. Kami diinapkan di mess TC dan selama pelatihan kami dilatih keterampilan menganyam hasil limbah pohon kelapa sawit berupa lidi menjadi berbagai alat rumah tangga seperti piring, pot bunga maupun keranjang buah. Dari 30 orang peserta terdapat sekitar 5 orang yang berhasil menjadi pengrajin sampai sekarang termasuk saya sendiri. Manfaat yang saya peroleh dari pelatihan tersebut adalah saya dapat menyalurkan minat berkreasi, menambah penghasilan dari usaha sampingan menganyam, dan saya sering diajak ikut pameran dan menjadi pengajar pelatihan yang dilaksanakan oleh Dekranasda Kab. Deli Serdang."

Sentra kriya yang merupakan bagian dari Rumah Pintar adalah wadah yang menyediakan berbagai aktivitas yang dirancang untuk memberikan keterampilan hidup dan keterampilan vokasional bagi masyarakat. Dengan adanya sentra kriya diharapkan tercipta perluasan peluang usaha dan peluang kerja bagi masyarakat setempat. Muara program ini adalah pada pengembangan jiwa kewirausahaan, pengenalan lingkungan, penggalian budaya pada anak-anak dan masyarakat setempat. Namun sayangnya, kegiatan pelatihan - pelatihan seperti ini 
semakin berkurang intensitasnya di Rumah Pintar Bagerpang.

Program CSR PT. PP London Sumatra Indonesia, Tbk yang lain adalah di bidang pendidikan. Pemberian beasiswa berprestasi adalah salah satu program CSR PT. Lonsum sebagai wujud kepedulian perusahaan di bidang pendidikan dalam rangka membantu program pemerintah mencerdaskan kehidupan bangsa. Menurut Muklis, karyawan Bagerpang Estate yang menangani pelaksanaan program CSR di perkebunan,

"Bantuan beasiswa diberikan oleh PT. Lonsum sebagai bentuk perhatian terhadap anak karyawan yang berprestasi, disamping sebagai bentuk sokongan bagi pendidikan mereka tetapi juga sebagai pendorong motivasi/semangat mereka dalam belajar. PT. Lonsum sendiri tidak membatasi berapa jumlah atau kuota penerima beasiswa ini setiap tahun. Kesempatan terbuka selebar-lebarnya untuk mendapatkan beasiswa ini, misalnya seorang karyawan memiliki 5 orang anak yang semuanya memperoleh prestasi akademis boleh mengajukan beasiswa untuk kelimanya. Beasiswa berprestasi ini diberikan untuk semua tingkat pendidikan dengan besaran beasiswa Rp150.000,00/tahun untuk siswa SD, Rp200.000,00/tahun untuk siswa SMP, Rp250.000,00/tahun untuk siswa SMA dan Rp300.000,00/tahun untuk mahasiswa perguruan tinggi karenanya jangan dilihat dari besaran nilai tapi dilihat dari nilai kebersamaan, pemberian beasiswa ini menjadi kebanggaan tersendiri bagi PT. Lonsum."

Beberapa tahun belakangan ini, PT. PP London Sumatra Indonesia, Tbk memprioritaskan anak - anak karyawannya sebagai penerima beasiswa berprestasi. Hal ini merupakan bentuk kepedulian dan penghargaan terhadap kinerja para karyawan selama ini dalam membesarkan perusahaan. Tentu saja harapan dari para perangkat desa sekitar perkebunan Bagerpang agar beasiswa berprestasi ini juga bisa dirasakan oleh anak -anak masyarakat sekitar perkebunan yang berstatus non karyawan PT. Lonsum. Demikian juga harapan dari para penerima beasiswa ini agar suatu saat besaran nilai rupiah yang diperoleh bisa ditingkatkan dari saat ini.

Berbagai bantuan yang diberikan oleh PT. PP London Sumatra Indonesia, Tbk memang memberikan manfaat dan membantu kehidupan masyarakat, namun disisi lain peneliti mempertanyakan apakah manfaat yang diterima tersebut sudah sesuai dengan tujuan dan sasaran program CSR yang ideal. Pelaksanaan CSR dalam perkembangannya mulai bergeser dari paradigma yang bersifat charity semata menjadi salah satu wujud partisipasi pembangunan yang mengarah kepada people centered development. Menurut Djayadiningrat (2004) salah satu sasaran CSR adalah terbentuknya masyarakat yang berdaya dalam meningkatkan kondisi sosial, ekonomi, budaya yang lebih baik di sekitar wilayah kegiatan perusahaan sehingga berdampak signifikan dalam upaya pengentasan kemiskinan dan meningkatnya partisipasi masyarakat dalam pembangunan karena sudah memiliki kemandirian dan mengoptimalkan potensi diri yang dimilikinya. Berdasarkan pemikiran tersebut implementasi CSR PT. Lonsum di wilayah Bagerpang Estate masih belum memenuhi kriteria tersebut karena masih berfokus pada bantuan jangka pendek yang bersifat amal. Adapun kegiatan pelatihan - pelatihan di sentra kriya rumah pintar yang bertujuan untuk melatih keterampilan karyawan dan masyarakat sekitar sehingga mereka bisa menghasilkan sebuah karya/produk yang bernilai ekonomis dari kreativitas mereka -pun masih belum maksimal pelaksanaannya.

\section{Faktor Pendukung \& Penghambat Keberhasilan Implementasi CSR}

Berikut faktor - faktor pendukung dan penghambat yang ditemui peneliti sebagai berikut:

Ketersediaan dana CSR. Program CSR sebagai salah satu pewujudan tanggung jawab sosial tentu saja membutuhkan pendanaan yang tidak sedikit. Menurut Budimanta dalam Rudito (2004), sumber pendanaan CSR setiap perusahaan diperoleh melalui cara menyisihkan laba tahunan, include ke dalam biaya produksi, atau menganggarkan biaya tersendiri/khusus CSR. PT. PP London Sumatra Indonesia, Tbk dalam hal ini memiliki sumber pendanaan CSR dengan jalan menganggarkan biaya khusus untuk sustainability department yang mengelola program CSR.

Koordinasi dan komunikasi yang terjalin baik. Partisipasi dan dukungan sangat diperlukan untuk menjalankan program program yang dirancang PT. PP London 
Sumatra Indonesia, Tbk, dukungan ini berasal dari internal perusahaan dan masyarakat selaku pihak eksternal. Dari observasi yang peneliti temukan di lapangan teridentifikasi bahwa dari pihak internal terdapat koordinasi dan komunikasi yang baik antara Tim Sustainability Department Kantor Medan dengan Tim CSR di Perkebunan Bagerpang pada saat perencanaan, pelaksanaan dan monitoring evaluasi CSR.

Selanjutnya, dari pihak eksternal, masyarakat penerima bantuan menyambut baik program CSR yang diberikan PT. Lonsum serta turut menjaga keharmonisan / meminimalisir timbulnya konflik di perkebunan sawit di wilayah Bagerpang.

Hal di atas sesuai dengan pemikiran Frynas (2009) bahwa diantara beberapa motif perusahaan untuk melakukan kegiatan CSR termasuk diantaranya adalah antara lain memenuhi peraturan pemerintah, memperoleh citra yang positif, mendapatkan licence to operate dari masyarakat setempat dan sebagai bagian dari risk management perusahaan untuk meredam dan menghindari konflik sosial.

Proses administrasi yang singkat. Hal ini terlihat pada program CSR PT. PP London Sumatra Indonesia, Tbk pada bantuan operasi bibir sumbing dan beasiswa berprestasi. Para penerima bantuan ini tidak dipersulit dengan persyaratan administrasi yang berbelit - belit. Pengurusan operasi penderita bibir sumbing hanya wajib memberikan salinan Kartu Keluarga dan penerima beasiswa berprestasi hanya perlu memperlihatkan rapor hasil belajar/surat keterangan juara kelas.

Agenda monitoring dan evaluasi CSR setiap tahun. Menurut Cultip dalam Suparman (2013), tahapan evaluasi harus dilakukan pada setiap akhir program atau kegiatan untuk melihat sejauh mana efektivitas dan efisiensinya. Manfaat dari kegiatan evaluasi CSR diantaranya, sebagai dasar perencanaan CSR di tahun berikutnya, menghindari kesalahan yang telah dilakukan, mengulangi kunci keberhasilan pelaksanaan CSR, dan memampukan perusahaan menyampaikan kepada para pemangku-kepentingan (pemegang-saham, pemerintah setempat, beneficiaries, dan masyarakat umum) tentang manfaat yang telah diciptakan perusahaan. PT. PP London Sumatra Indonesia, Tbk mengagendakan kegiatan monitoring dan evaluasi kegiatan CSR setiap tahun yang dipimpin pelaksanaannya oleh Sustainability Manager dan dapat dibantu oleh konsultan pihak ketiga yang ditetapkan perusahaan.

Berikut dijabarkan factor-faktor penghambat yang muncul dalam implementasi program CSR PT. Lonsum di Bagerpang Estate yaitu:

Peraturan organik dari kebijakan CSR belum terbentuk. Kebijakan tentang pelaksanaan tanggung jawab sosial/CSR perusahaan tercantum dalam Undang - Undang no. 40 tahun 2007 tentang Perseroan Terbatas, Undang - Undang Penanaman Modal no. 25 tahun 2007 dan Undang - Undang no. 32 tahun 2009. Namun sampai saat ini belum ada peraturan organik/peraturan turunan dari undang - undang tersebut yang mengikat perusahaan secara pasti dalam bentuk peraturan pelaksanaan. Di Indonesia, peraturan mengenai CSR mewajibkan perusahaan yang menggunakan sumber daya alam untuk mengalokasikan 2-4\% dari keuntungannya kepada pemerintah, namun peraturan ini perlu ditinjau kembali dan diberi penekanan karena muncul persepsi yang berbeda-beda dan tidak adanya definisi yang jelas. Kemudian terkait pelanggaran aturan, tidak disebutkan sanksi apa yang diterima oleh perusahaan apabila tidak melaksanakan kewajiban tanggung jawab sosialnya. Tentu saja hal ini menjadi titik lemah untuk pelaksanaan program CSR yang ideal.

\section{Konsep implementasi perusahaan} tentang CSR belum mengacu pada pemberdayaan masyarakat. Indonesia adalah salah satu negara yang ikut berkomitmen untuk mengintegrasikan MDGs (Millennium Development Goals) sebagai bagian dari program pembangunan nasional dalam upaya menangani penyelesaian terkait dengan isu-isu yang sangat mendasar seperti kemiskinan, pendidikan, kesehatan, kesetaraan gender, kelestarian lingkungan hidup, dan kemitraan global. Dalam rangka mewujudkan tujuan ini, pemerintah memerlukan sinergitas yang baik dengan pihak-pihak terkait termasuk korporasi. Korporasi diupayakan dapat memaksimalkan perannya dalam pelaksanaan tanggung jawab sosial dan lingkungan dalam bentuk implementasi CSR. Kenyataannya, sebagian perusahaan masih memfokuskan sasaran pelaksanaan CSR nya pada level peningkatan kualitas hidup karyawan dan 
keluarganya. Di PT. PP London Sumatra Indonesia, Tbk beberapa program CSR hanya ditujukan untuk kemaslahatan karyawan dan keluarganya.

Pemetaan masalah sosial belum terlaksana dengan baik. Pemetaan masalah sosial merupakan satu metode yang dilakukan untuk menemukenali dan mendalami kondisi sosial suatu komunitas/masyarakat. Pada tahapan perencanaan program CSR, perlu diadakan pemetaan masalah sosial yang terjadi di tengah - tengah masyarakat, sehingga akan terbentuk agenda CSR yang jelas dan terarah serta sesuai dengan kebutuhan masyarakat.

Pada tahap perencanaan program CSR, PT. PP London Sumatra Indonesia, Tbk tidak melibatkan partisipasi masyarakat. Hal ini dilakukan untuk menghindari miskomunikasi/konflik apabila ada permintaan/tuntutan masyarakat yang tidak bisa diakomodir oleh perusahaan sementara di lain pihak masyarakat merasa aspirasi mereka telah tersampaikan dan sangat berharap dikabulkan.

Belum adanya transparansi tentang penggunaan anggaran CSR. Pengelolaan dana CSR perusahaan harus bersifat transparan dan terbuka bagi masyarakat dan pemerintah. Masyarakat seharusnya mengetahui anggaran dana CSR perusahaan dan kemana saja disalurkan, apakah diprioritaskan kepada masyarakat sekitar wilayah operasional perusahaan atau tidak sehingga dana CSR tersalurkan dengan semestinya. Kenyataannya, sampai saat ini masih terdapat beberapa perusahaan yang belum terbuka mengenai alokasi anggaran CSR mereka. PT. PP London Sumatra Indonesia, Tbk dalam hal ini menganggap permasalahan anggaran CSR dan realisasinya merupakan hal yang bersifat confidential bagi perusahaan, harus dirahasiakan. Menurut manajemen perusahaan, hal ini dilakukan untuk menjaga segala kemungkinan negatif yang terjadi yaitu menghindari penyalahgunaan informasi yang dilakukan pihak - pihak yang memiliki tujuan tidak baik.

\section{SIMPULAN}

Salah satu upaya pemerintah untuk mempercepat penanggulangan kemiskinan adalah melalui kebijakan CSR yang wajib dilakukan perusahaan secara berkesinambungan dan berkelanjutan. Lewat upaya pemerintah ini diharapkan terjadinya sinergitas kebijakan pemberdayaan masyarakat dengan semua program penanggulangan kemiskinan di daerah sebagai wujud tanggung jawab sosial perusahaan.

Masyarakat yang berada disekitar lokasi operasional perusahaan adalah salah satu pihak yang dapat memengaruhi keberadaan dan keberlanjutan suatu perusahaan. Oleh karena itu perusahaan sangat perlu menjaga keseimbangan dengan masyarakat khususnya yang berada di sekitar lokasi operasional perusahaan dalam rangka menjaga eksistensinya. Keseimbangan ini dapat dijaga dengan melakukan tanggung jawab sosial perusahaan.

Keberadaan PT. Lonsum di tengah tengah kehidupan masyarakat desa sekitar perkebunan telah memberikan manfaat sejak perkebunan Bagerpang ini dibuka, terutama terserapnya tenaga kerja yang berasal dari masyarakat dan bantuan - bantuan lain yang diberikan melalui praktik CSR. Dari hasil analisis data penelitian, peneliti menemukenali beberapa faktor penghambat keberhasilan dan efektivitas implementasi CSR di PT. PP London Sumatra Indonesia, Tbk. Faktor - faktor penghambat yang teridentifikasi selama penelitian dapat menjadi masukan bagi perusahaan untuk ditemukan solusinya agar pelaksanaan CSR bisa lebih efektif, efisien, dan tepat sasaran serta membawa manfaat untuk semua stakeholder. Pada tahapan perencanaan/penyusunan program CSR, pihak perusahaan semestinya membuat pertemuan dengan masyarakat untuk menampung aspirasi dan keluhan masyarakat sehingga melahirkan kesepakatan secara tertulis antara perusahaan dan masyarakat yang nantinya bermuara kepada program CSR yang sesuai dengan kebutuhan masyarakat dan lingkungan sekitar. Diharapkan program - program CSR PT. PP London Sumatra Indonesia, Tbk ke depannya lebih fokus kepada upaya penguatan potensi sumber daya manusia sehingga masyarakat mampu menjadi penggerak kegiatan ekonomi kerakyatan.

\section{DAFTAR PUSTAKA}

Frynas, J.G. (2009). Beyond Corporate Social Responsibility, Oil Multinationals and Social Challenges. Cambridge: Cambridge University Press.

Keputusan Menteri BUMN Nomor: Kep236/MBU/2003 mengatur tentang Program 
Kemitraan Badan Usaha Milik Negara dengan Usaha Kecil dan Program Bina Lingkungan (PKBL)

Maszoom, Z. (2016). Peran Corporate Social Responsibility (CSR) dalam Mendorong Pembangunan Berkelanjutan di Indonesia.

Maygarindra, P.B. \& El Maghviroh, R. (2012). Analisis Alokasi Dana Corporate Social Responsibility serta Pelaporan Sustainability Report Berdasarkan Global Reporting Initiative (GRI G3) Di PT. Pembangkitan Jawa Bali. The Indonesian Accounting Review Volume 2 No. 2 July 2012 pages 173 - 184 . STIE Perbanas Surabaya.

Nasution, S. (1991). Metode Research Penelitian Ilmiah. Bandung: Jermais.

Rudito, B., Budimanta, A., \& Prasetijo, A. (2004). Corporate Social Responsibility: Jawaban Bagi Modal Pembangunan Indonesia Masa Kini. Jakarta: ICSD.

Sari, W. P., Ratnadi, N. M. D., Laxmi, L., Shankar, K., \& Wiflihani, W. (2020). Corporate Social
Responsibility (CSR): Concept of The Responsibility of The Corporations. Journal of Critical Reviews, 7(1), 241-245.

Soleh, A. (2012). Analisis Pertumbuhan Ekonomi dan Kesenjangan Pembangunan Ekonomi Antar Region Di Indonesia Tahun 2001-2010. Jurnal Ekonomi Dan Perencanaan Pembangunan (JEPP), 04(03).

Suparman. (2013). "Corporate Social Responsibility: Bentuk Tanggung Jawab Sosial dan Kepedulian Perusahaan dengan Masyarakat". Jurnal Interaksi, II(2) : 69-81.

Undang - Undang No. 11 Tahun 2009 tentang Kesejahteraan Sosial.

Undang - Undang No. 25 Tahun 2007 tentang Penanaman Modal.

Undang - Undang No. 40 Tahun 2007 tentang Perseroan Terbatas.

Wrihatnolo, R., dan Dwidjowijoto, R.N. (2008). Manajemen Pembangunan Indonesia, Sebuah Pengantar dan Panduan. Jakarta: Gramedia Elexmedia. 